\title{
KESANTUNAN BAHASA GURU DALAM PROSES BELAJAR- MENGAJAR DI SMP NEGERI 35 MAKASSAR
}

\author{
Asdar $^{1}$, Hamsiah $^{2}$, A. Vivit Angreani ${ }^{3}$ \\ Fakultas Keguruan dan Ilmu Pendidikan, Universitas Bosowa, Makassar, Indonesia
}

\begin{abstract}
ABSTRAK
Penelitian ini bermaksud mendeskripsikan kesantunan bahasa lisan guru dalam proses belajar-mengajar di SMP Negeri 35 Makassar. Hal yang mendorong peneliti melakukan penelitian ini adalah karena dalam proses belajar-mengajar terjadi beberapa jenis komunikasi, yaitu komunikasi guru - siswa, siswa - guru, dan siswa - siswa. Namun, fokus penelitian ini adalah tuturan guru terhadap siswa. Hal lain yang memotivasi penulis adalah faktor heterogenitas peserta tutur, yaitu bervariasinya latar belakang peserta tutur di SMP Negeri 35 Makassar, khusunya guru. Adapun teknik pengumpulan data yang digunakan adalah teknik observasi yang meliputi teknik simak bebas libat cakap, yaitu peneliti melakukan pengamatan terhadap situasi di kelas tanpa melibatkan diri dalam percakapan. Sedangkan teknik rekam dimaksudkan peneliti merekam percakapan atau pembicaraan di kelas dengan menggunakan tape recorder. Hasil penelitian menunjukkan bahwa 581 tuturan guru yang diperoleh dan 59\% di antaranya dikategorikan santun. Faktor-faktor yang memengaruhi kesantunan bahasa guru adalah faktor jarak sosial antara guru dan siswa, faktor penguasaan aspek kebahasaan, dalam hal ini penguasaan guru tentang kaidah-kaidah kesantunan bahasa, dan faktor kedewasaan guru. Penanda kesantunan yang ditemukan adalah adanya penggunaan kata-kata 'mohon', 'tolong', 'ayo', 'mari'. Selain itu, guru juga berusaha menyantunkan tuturan dengan menggunakan skala ketidaklangsungan tuturan dan pemberian pilihan dalam bertutur
\end{abstract}

Kata kunci: Kesantunan Bahasa, belajar-mengajar, bahasa lisan, guru

\section{PENDAHULUAN}

Secara umum, bahasa dipahami sebagai sarana komunikasi. Salam satu komponen komunikasi adalah peristiwa komunikasi. Di dalam peristiwa komunikasi terdapat unsur penting, di antaranya penutur dan mitra tutur. Komunikasi berlangsung bukan hanya ditentukan oleh faktor linguistik, melainkan juga oleh faktor nonlinguistik, seperti faktor sosial dan faktor situasional. Faktor sosial meliputi status sosial, tingkat pendidikan, tingkat ekonomi, usia, dan jenis kelamin. Sedangkan faktor situasional mencakup siapa berbicara, kepada siapa, kapan, dan seterusnya. Hal ini memengaruhi cara pancang penutur dalam menentukan pilihan ragam bahasa untuk berkomunikasi dengan lawan tutur.

Yang menjadi pertimbangan dalam pemakaian bahasa, di samping tercapainya ntujuan komunikasi, di antaranya kepada siapa atau tentang siapa komunikasi itu berlangsung. Faktor tersebut, menurut Akhadiat (1992), berkaitan erat dengan nilainilai etika yang berlaku di dalam masyarakat. oleh karena itu, dalam penggunaan bahasa ada bentuk dan ungkapan tertentu yang dipergunakan jika berbicara kepada atau tentang orang yang lebih tua atau tentang orang yang lebih dihormati. Misalnya, kata sapaan "Bapak" atau "Ibu", serta kata ganti "beliau", hanya dipergunakan dalam hubungannya dengan orang yang dihormati, atau memiliki kedudukan yang lebih tinggi. 
Di samping itu, ada ungkapan-ungkapan tertentu yang dijadikan sebagai pemarkah pelembut suruhan atau permintaan, seperti kata-kata mohon, silakan, harap, diminta, dan tolong. Kepada wanita misalnya, orang akan berbicara lebih lembut dan sopan. Kesemua itu merupakan tata krama dalam pemakaian bahasa yang sering disebut santun berbahasa.

Berbahasa santun adalah salah satu bentuk keterampilan berbahasa manusia. Keterampilan berbahasa santun tidak sertamerta dimiliki oleh manusia, tetapi harus melalui proses pendidikan. Berbahasa santun itu perlu ditanamkan kepada anak-anak sejak usia dini. Hal ini merupakan aspek etika yang sangat penting. Itulah sebabnya, berbicara diajarkan di sekolah sebagai salah satu aspek keterampilan berbahasa. Begitu pentingnya aspek keterampilan berbicaa ini sehingga baik kurikulum berbasis kompetensi maupun kurikulum 2013 mengharapkan agar siswa dapat mengungkapkan pendapat, pikiran, perasaan dengan bahasa santun sebagai salah satu keberhasilan siswa dalam belajar.

Dalam hubungannya dengan pembelajaran bahasa Indonesia di kelas, ada tiga jenis pola komunikasi yang terjadi, yaitu komunikasi sebagai aksi, komunikasi sebagai interaksi, dan komunikasi sebagai transaksi (Sudjana, 1989). Komunikasi sebagai aksi (komunikasi satu arah) menempatkan guru sebagai pemberi aksi dan siswa sebagai penerima aksi mengajar, dalam hal ini dipandang sebagai kegiatan menyampaikan bahan pelajaran. Dalam komunikasi sebagai interaksi atau komunikasi dua arah, guru berperan sebagai pemberi aksi atau penerima aksi. Demikian pula halnya siswa, mereka dapat berperan sebagai pemberi aksi dan juga penerima aksi, sehingga antra guru dan siswa akan terjadi dialog. Sedangkan, dalam komunikasi sebagai transaksi (komunikasi banyak arah), komunikasi tidak hanya terjadi antara guru dan siswa, tetapi komunikasi dapat berlangsung antarsiswa. Siswa dituntut lebih aktif daripada guru. Guru dapat berfungsi sebagai sumber belajar bagi siswa lain. Di antara ketiga pola komunikasi tersebut, komunikasi transaksi dianggap sesuai dengan konsep belajar yang menekankan keaktifan siswa. Sehubungan dengan bentuk interaksi belajar-mengajar tersebut, dapat ditemukan tiga arah komunikasi, yaitu komunikasi guru terhadap siswa, siswa terhadap guru, dan komunikasi antarsiswa.

Di Kota Makassar terdapat sebuah sekolah yang menerapkan sistemn pembelajaran dengan penekanan pada keaktifan siswa. Tentunya, dalam proses belajar-mengajar di kelas terjadi komunikasi transaksi. Sekolah yang dimaksud adalah SMP Negeri 35 Makassar. Masyarakat sekolah tersebut, terutama guru dan siswa memiliki latar belakang yang sangta heterogen. Guru bahasa Indonesia yang ada di sekolah tersebut berjumlah 5 orang dengan kualifikasi sarjana (S-1 dan S-2). Di pihak lain, siswa berjumlah 672 yang terbagi atas 18 kelas. Setiap kelas berkapasitas kurang lebih 37 siswa. Antara guru dan siswa terdapat perbedaan, terutama dalam hal usia dan pendidikan. Demikian pulan, antara siswa yang satu dan siswa yang lain memiliki kaakteristik yang berbeda-beda. Perbedaan itu dapat dilihat dari segi ekonomi, pendidikan, orang tua, jenis kelamin, dan status sosial keluarga. Faktor yang dapat menyamakan mereka adalah faktor usia. Mereka berusia rata-rata $12-15$ tahun.

Gambaran tentang heterogenitas ini memungkinkan terjadinya perbedaan kesantunan berbahasa di antara peserta tutur/komunikasi dalam proses belajarmengajar. Hal ini menjadi motivasi bagi penulis untuk mengkaji kesantuan bahasa guru di SMP Negeri 35 Makassar.

\section{KAJIAN PUSTAKA}

Mengajar telah mengalami perubahan paradigma dari konvensional menjadi kekinian. Mengajar tidak lagi dipahami sebagai upaya mengajari siswa 
ilmu pengetahuan. Akan tetapi, lebih dari itu, siswa diajari cara belajar. implikasinya adalah di dalam kelas terjadi berbagai macam pola interaksi. Pola interaksi yang dimaksud paling tidak pola guru - siswa, siswa - guru, dan pola antarsiswa. Dalam kegiatan interaksi ini bahasa sangat dibutuhkan. Guru sebagai individu yang membelajarkan siswa diharapkan dapat memainkan fungsi-fungsi bahasa. Halliday dalam Tarigan (1990) mengemukakan fungsi-fungsi bahasa, yaitu:

1. Fungsi instrumental: bahasa digunakan untuk melayani pengelolaan lingkungan, menyebabkan peristiwa-peristiwa tertentu terjadi.

2. Fungsi regulasi: bertindak untuk mengawasi serta mengendalikan peristiwa-peristiwa.

3. Fungsi pemerian: penggunaan bahasa untuk membuat pernyataan-pernyataan, menyampaikan fakta-fakta dan pengetahuan, menjelaskan atau melaporkan dengan kata lain menggambarkan, memerikan realitas yang sebenarnya, seperti yang dilihat oleh seseorang.

4. Fungsi interaksi: bertugas untuk menjamin serta memantapkan ketahanan dan kelangsungan komunikasi, interaksi sosial. Keberhasilan komunikasi interaksional ini menuntut pengetahuan secukupnya mengenai logat, lelucon, cerita rakyat, adat-istiadat dan budaya setempat, tata krama pergaulan, dan sebagainya.

5. Fungsi perorangan: memberi kesempatan kepada seorang penutur untuk mengekspresikan perasaan, emosi, pribadi, serta reaksi-reaksinya yang mendalam. Keperibadian seseorang biasanya ditandai oleh penggunaan fungsi personal bahasanya dalam berkomunikasi dengan orang lain.

6. Fungsi heuristik: melibatkan penggunaan bahasa untuk memperoleh ilmu pengetahuan, mempelajari seluk-beluk lingkungan. Fungsi heuristik ini sering disampaikan dalam bentuk pertanyaanpertanyaan yang menuntut jawabab.

7. Fungsi imajinatif: melayani penciptaan sistem-sistem atau gagasan-gagasan yang bersifat imajinatif. Mengisahkan ceritacerita dongeng, membacakan lelucon, atau menulis novel merupakan praktik penggunaan fungsi imajinatif bahasa.

Berbicara tentang kesantunan bahasa guru, Leech (1983) memaparkan enam maksim interpersonal, yaitu (1) maksim kebijaksanaan: guru sebagai pembicara berusaha mengurangi kerugian orang lain dan menambah keuntungan orang lain dalam bertutur; (2) maksim kedermawanan: guru sebagai pembicara mengurangi keuntungan diri sendiri dan menambah pengorbanan diri sendiri; (3) maksim penghargaan: maksim ini menghendaki pembicara (guru) untuk mengurangi cacian terhadap orang lain dan menambah cacian terhadap diri sendiri; (4) maksim kesederhanaan: penutur (guru) mengurangi pujian terhadap diri sendiri dan menambah cacian pada diri sendiri; (5) maksim permufakatan: penutur menguangi ketidaksesuaian antara diri sendiri dengan orang lain; dan (6) maksim simpati: maksim yang menghendaki penutur agar mengurangi antipati antara diri sendiri dengan orang lain.

Untuk mengukur perinkat kesantunan tuturan seseorang, selanjutnya Leech mengemukakan skala kesantunan bahasa, yaitu:

a. Skala kerugian dan keuntungan: semakin tuturan itu merugikan diri penutur, semakin santunlah tuturan tersebut.

b. Skala pilihan: semakin leluasa lawan tutur menentukan pilihan, semakin santunlah tuturan tersebut.

c. Skala ketidaklangsungan: semakin tidak langsung maksud sebuah tuturan, akan dianggap semakin santunlah tuturan tersebut.

d. Skala keotoritasan: semakin jauh jarak peringkat sosial antara penutur dan mitra tutur, tuturan yang diproduksi akan cenderung semakin santun. 
e. Skala jarak sosial: tingkat keakraban hubungan antara penutur dan mitra tutur, sangat menentukan peringkat kesantunan tuturan yang digunakan dalam bertutur..

\section{METODE PENELITIAN}

Penelitian ini bersifat deskriptif kualitatif. Artinya, peneliti berusaha mencatat secara detail dan teliti semua fenomena kebahasaan yang terjadi. Dengan kata lain, dapat dikatakan bahwa dalam penelitian deskriptif peneliti berusaha memerikan sistem bahasa berdasarkan data yang sebenarnya ada. Penelitian ini dilaksanakan di SMP Negeri 35 Makassar dengan pertimbangan (1) di sekolah tersebut diterapkan pendekatan belajar yang berorientasi pada keaktifan siswa, (2) di dalam proses belajar-mengajar digunakan bahasa Indonesia sebagai bahasa pengantar dalam komunikasi sehingga dapat diidentifikasi kesantunan bahasa guru, (3) guru memiliki latar belakang yang berbeda, dan (4) terjadi komunikasi dengan pola interaksi guru - siswa.

Penelitian ini dikategeorikan sebagai penelitian deskriptif kualitatif dengan fokus kajian diarahkan pada kesantunan bahasa guru (dalam hal ini bahasa lisan guru) dalam proses belajar-mengajar bahasa Indonesia.

Data dalam penelitian ini adalah bahasa lisan guru yang mengandung ciri kesantunan yang muncul dalam proses belajar-mengajar ketika terjadi komunikasi atau interaksi guru - siswa. Dengan demikian, yang menjadi sumber data adalah tuturan atau bahasa lisan guru.

Teknik pengumpulan data yang digunakan dalam penelitian ini adalah teknik observasi atau pengamatan langsung serta teknik simak. Teknik simak, menurut Alwasilah (2003), dilakukan dengan cara mengamati secara saksama percakapan dalam PBM tuturan guru ke siswa di SMP Negeri 35 Makassar. Metode simak, menurut Mahsun (2005), dilakukan dengan menggunakan teknik, yaitu (1) simak bebas libat cakap (peneliti tidak terlibat langsung dalam pembicaraan, tetapi hanya sebagai pengamat), (2) rekam, yaitu peneliti merekam percakapan dengan menggunakan alat perekam berupa tape recorder, dan (3) catat, yaitu peneliti mencatat data penelitian yang diperoleh di lapangan dan ditulis dalam kartu-kartu data yang telah disiapkan.

Agar pembahasan dapat tersusun dengan baik, terstruktur, dan tidak simpang siur, analisis data dilakukan dengan langkahlangkah tertentu sesuai dengan urutan-urutan pembahasannya. Urutan-urutan tersebut dimulai dengan:

1. Menskrip data rekaman ke dalam bentuk tulisan;

2. Mengklasifikasi kelompok penutur dan bentuk konstruksinya;

3. Mengidentifikasi kategori dan ungkapan penanda kesantunan tuturan guru;

4. Data disajikan dalam bentuk deskripsi kualitatif sebagaimana adanya.

Setelah data disediakan dengan baik, dalam arti telah diklasifikasi, diidentifikasi dengan cukup teliti, dan dianalisis kesantunan tiap tuturan, tahapan berikutnya adalah menentukan tingkat kesantunannya dengan menggunakan skala peringkat kategori (category rating scale) yang terdiri atas empat kategori, yaitu (1) sangat santun, (2) santun, (3) tidak santun, dan (4) sangat tidak santun (Abustam, 2006).

Tabel 1 Skala peringkat kesantunan bahasa guru di SMP Negeri 35 Makassar.

\begin{tabular}{ll}
\hline Interval & Kategori \\
\hline $\mathbf{7 6 \%}-\mathbf{1 0 0 \%}$ & Sangat santun \\
$\mathbf{5 1 \%}-\mathbf{7 5 \%}$ & Santun \\
$\mathbf{2 6 \%} \mathbf{- 5 0 \%}$ & Tidak santun \\
$\mathbf{0 \%}-\mathbf{2 5 \%}$ & Sangat tidak santun \\
\hline
\end{tabular}




\section{HASIL PENELITIAN DAN PEMBAHASAN}

Hasil penelitian menunjukkan bahwa dalam proses belajar-mengajar bahasa Indonesia diperoleh 581 tuturan guru terhadap siswa. Kemudian, ditemukan 56\% di antaranya dikategorikan santun.

Proses belajar-mengajar sebagai peristiwa komunikasi melibatkan dua komponen peserta tutur, yaitu guru dan siswa. Kedua komponen peserta tutur itu memiliki perbedaan pada hampir seluruh aspek, seperti usia, status sosial, latar belakang pendidikan, dan sebagainya. Dari segi usia, guru bahasa Indonesia SMP Negeri 35 Makassar lebih tua daripada siswa. Dari segi pendidikan, guru lebih unggul daripada siswa yang dibuktikan gelar kesarjaan $\mathrm{u}=$ yang dimiliki guru. Dari segi status sosial. Guru memiliki kedudukan lebih tinggi di dalam kelas dibandingkan kedudukan siswa.

Sehubungan dengan itu, telah disinggung pada bagian sebelumnya bahwa santun atau tidaknya sebuah tuturan disebabkan oleh beberapa hal, di antaranya (1) semakin tua/dewasa umur seseorang semakin santun tuturan yang dituturkannya, dan sebaliknya, semakin muda usia seseorang semakin tidak santun tuturan yang diungkapkannya; (2) semakin jauh jarak peringkat sosial antara penutur dan mitra tutur, semakin santun pula tuturannya, demikian pula sebaliknya; dan (3) latar belakang sosio-kultural turut pula berpengaruh terhadap tuturan penuturnya.

Data yang menunjukkan bahwa bahasa lisan guru terhadap siswa masuk kategori santun mendukung pandangan yang mengatakan bahwa semakin tua/dewasa umur seseorang semakin santun dalam bertutur. Ditambah lagi bahwa kelima guru bahasa Indonesia SMP Negeri 35 Makassar yang dijadikan sumber data penelitian ini berkualifikasi strata satu (S-1) dan strata dua (S-2). Hal ini mengindikasikan bahwa guru telah memiliki wawasan kebahasaan yang memadai, khusunya dalam hal kesantunan bahasa.

Namun, jika dilihat dari faktor usia dan faktor kematangan pendidikan, sebenarnya diharapkan tuturan guru terhadap siswa berada pada kategori sangat santun. Tapi, kenayataannya hanya berada pada kategori santun. Hal ini dapat dikaitkan pada teori kesantunan yang mengatakan bahwa skala peringkat sosial seseorang dapat menyebabkan kurangnya kesantunan bahasa yang dituturkannya karena seseorang yang berada pada kedudukan yang lebih tinggi daripada mitra tutur bisa menyebabkan tuturannya kurang santun. Sebagai contoh, seorang kakak bertutur kepada adiknya, tuturannya lebih cenderung memiliki sifat kelangsungan tanpa menggunakan penandapenanda kesantunan bahasa.

\section{KESIMPULAN}

Berdasarkan hasil penelitian mengenai kesantunan bahasa guru terhadap siswa di SMP Negeri 35 Makassar dapat disimpulkan bahwa tuturan guru terhadap siswa dikategorikan santun. Hal ini ditunjukkan oleh data bahwa dari 581 tuturan yang diperoleh, $59 \%$ di antaranya dikateorikan santun. Adapun faktor memengaruhinya adalah faktor kedewasaan dan faktor penguasaan teori-teori kesantuna bahasa. Selain itu, juga dipengaruhi oleh faktor jarak sosial antara guru dan siswa..

\section{DAFTAR PUSTAKA}

Abustam, M.Idrus. (2006). Rating Scale (Makalah). Disajikan pada seminar dalam rangka Dies Natalis IX PPs UNM pada tanggal 6 Juli di Makassar.

Akhadiah, Sabarti, dkk. (1992). Bahasa Indonesia I. Departemen Pendidikan dan Kebudayaan. Direktorat Jenderal Pendidikan Tinggi Proyek Pembinaan Tenaga Kependidikan. 
Alwasilah, A. Chaedar. (2003). Pokoknya Kualitatif; Dasar-Dasar Merancang dan Melakukan Penelitian Kualitatif. Jakarta: Kiblat Buku Utama.

Eelen, Gino. (2006). Kritik Teori Kesantunan. Surabaya: Airlangga University Press.

Ismari. (1995). Tentang Percakapan. Surabaya: Airlangga University Press.

Kushartanti dkk. (2005). Pesona Bahasa; Langkah Awal Memahami Linguistik. Jakarta: Gramedia Pustaka Utama.

Leech, Geoffrey N. (1983). Principles of Pragmatik. London: Longman.

Rahardi, R. Kunjana. (2005). Pragmatik; Kesantuan Imperatif Bahasa Indonesia. Jakarta: Erlangga.

Suryalaga. (1993). Etika Jeung Tata Krama. Bandung: Gegersunen.

Tarigan, HG. (1990). Pengajaran Pragmatik. Bandung: Angkasa. 